\title{
Implementing green supply chain practices: an empirical investigation in the shipbuilding industry
}

Citation for published version (APA):

Caniels, M. C. J., Cleophas, E., \& Semeijn, J. (2016). Implementing green supply chain practices: an empirical investigation in the shipbuilding industry. Maritime Policy \& Management, 43(8), 1005-1020. https://doi.org/10.1080/03088839.2016.1182654

Document status and date:

Published: 01/01/2016

DOI:

10.1080/03088839.2016.1182654

Document Version:

Publisher's PDF, also known as Version of record

\section{Please check the document version of this publication:}

- A submitted manuscript is the version of the article upon submission and before peer-review. There can be important differences between the submitted version and the official published version of record.

People interested in the research are advised to contact the author for the final version of the publication, or visit the DOI to the publisher's website.

- The final author version and the galley proof are versions of the publication after peer review.

- The final published version features the final layout of the paper including the volume, issue and page numbers.

Link to publication

\footnotetext{
General rights rights.

- You may freely distribute the URL identifying the publication in the public portal. please follow below link for the End User Agreement:

www.umlib.nl/taverne-license

Take down policy

If you believe that this document breaches copyright please contact us at:

repository@maastrichtuniversity.nl

providing details and we will investigate your claim.
}

Copyright and moral rights for the publications made accessible in the public portal are retained by the authors and/or other copyright owners and it is a condition of accessing publications that users recognise and abide by the legal requirements associated with these

- Users may download and print one copy of any publication from the public portal for the purpose of private study or research.

- You may not further distribute the material or use it for any profit-making activity or commercial gain

If the publication is distributed under the terms of Article $25 \mathrm{fa}$ of the Dutch Copyright Act, indicated by the "Taverne" license above, 


\section{Implementing green supply chain practices: an empirical investigation in the shipbuilding industry}

\section{Marjolein C. J. Caniëls, Eugène Cleophas \& Janjaap Semeijn}

To cite this article: Marjolein C. J. Caniëls, Eugène Cleophas \& Janjaap Semeijn (2016) Implementing green supply chain practices: an empirical investigation in the shipbuilding industry, Maritime Policy \& Management, 43:8, 1005-1020, DOI: 10.1080/03088839.2016.1182654

To link to this article: http://dx.doi.org/10.1080/03088839.2016.1182654
(c) 2016 The Author(s). Published by Informa UK Limited, trading as Taylor \& Francis Group

Published online: 17 May 2016.

Submit your article to this journal 중

$$
\text { Џ Article views: } 249
$$

Q View related articles $₫$

View Crossmark data $\nearrow$ 


\title{
Implementing green supply chain practices: an empirical investigation in the shipbuilding industry
}

\author{
Marjolein C. J. Caniëls 이, Eugène Cleophas and Janjaap Semeijn
}

Faculty of Management, Science and Technology, Open University of the Netherlands, Heerlen, the Netherlands

\begin{abstract}
Environmental concerns have become important in the shipbuilding industry. Governmental expectations about environmental and social performance are much higher than in the past. Public authorities penalize companies that do not comply with the rules. Shipbuilding companies face these challenges by introducing new technologies into their business processes. They do not only start initiatives to green their own business processes but also those of their supply chain partners. This form of environmental management is called Green Supply Chain Management (GrSCM) and its importance is increasingly recognized. Although GrSCM is growing, companies are experiencing difficulties engaging suppliers in environmental activities.

This empirical study analyses drivers for supply chain participation of suppliers in the shipbuilding industry. We explain the participations of suppliers in GrSCM practice by investigating influencing factors including governmental involvement in greening the supply chain, customer requirements towards green issues, feeling of social responsibility, competitive advantage by going green, and GrSCM readiness. Hypotheses are tested with partial least squares, using survey data of 93 suppliers of two leading shipbuilding companies. We found GrSCM readiness, competitive advantage, and social responsibility to be significant drivers in supplier participation. No significant support was found for governmental involvement and customer requirements.
\end{abstract}

\section{KEYWORDS}

Environmental management; technological progress; supplier-buyer relations; supply chain; shipbuilding

\section{Introduction}

As the society increasingly becomes aware of global warming and environmental issues, companies are more and more questioned about the environmental friendliness of their production process and supply chain (Andersen and Skjoett-Larsen 2009; Koller, Floh, and Zauner 2011), their environmental footprint, and their recycle policy (Seuring and Müller 2008). This holds for a wide spectrum of industries. However, transport-related industries such as the automobile, aviation, and maritime industries are particularly under scrutiny of the public opinion, as these industries have a public image of being environmentally unfriendly.

Social and regulatory dynamics are putting real pressures on companies in all sectors to be both lean and green in their product sourcing, logistics, distribution, and operational practices (Awaysheh and Klassen 2010; Caniëls, Gehrsitz, and Semeijn 2013). Furthermore, companies have to keep up with environmental practices, because of competitive reasons. Competitors are also going green, and a single firm cannot afford to stay behind. The need for adapting to social and 
market forces goes beyond affecting strategies of individual firms. For companies it is increasingly important to justify their sourcing strategies and pay attention to the greening policies of their suppliers. Therefore, it is of utmost importance for companies to involve their suppliers in green supply chain initiatives (Lee and Klassen 2008). To date, only few studies have investigated this issue (Caniëls, Gehrsitz, and Semeijn 2013; Xu et al. 2013). Studies in the field of green supply chain management predominantly focus on the focal firm's internal operations (e.g. Kang, Ryu, and Kim 2010) or green market practices (e.g. Cronin et al. 2011), instead of addressing the internal organizational processes of suppliers. There is a call for empirical research that studies supplier motivations to take part in green supply chain initiatives (Prahinski and Kocabasoglu 2006).

The shift towards environmental consciousness has far-reaching implications for the shipbuilding industry, which is an industry that is involved in designing, building and constructing, converting and upgrading of vessels as well as marine equipment manufacturing. Over the last decades measures have been undertaken to green production facilities. Additionally, more recently, suppliers are motivated to participate in green supply chain initiatives (Lai et al. 2011). Whereas work already has been done with regard to identifying the ways in which suppliers can be motivated in industries such as automotive (e.g. Caniëls, Gehrsitz, and Semeijn 2013; Xu et al. 2013), the shipbuilding industry has remained rather obscure as an object of study (Lam and Van de Voorde 2011). Yet, this industry is particularly interesting as greening initiatives have been developing recently, and much can still be gained with regard to sustainability compliance (Lai et al. 2011). The shipbuilding industry has many specific characteristics that make it interesting and relevant for studying GrSCM practices, including its highly competitive and global nature (Lu and Tang 2000; Levering et al. 2013), and its capital intensity and project-based organization following engineering to order principles (Mello and Strandhagen 2011). Moreover, studies about the maritime industry call for further research on drivers for supplying industries to embrace green practices in their operations (Lai et al. 2011).

The aim of our paper is to shed light on the drivers and motivators that influence the involvement and/or participation of suppliers in GrSCM initiatives in shipbuilding. Which drivers affect the implementation of GrSCM initiatives and what is their relative importance? By explicitly surveying shipbuilding suppliers, we contribute to the understanding of supplier's views and perceptions with regard to their motivations to participate in green initiatives of their buyers. Hereby we address the quest for more research to the supplier side (Lee and Klassen 2008; Caniëls, Gehrsitz, and Semeijn 2013).

\section{Background}

The concept of GrSCM is defined as integrating environmental thinking into supply-chain management, including product design, material sourcing and selection, manufacturing processes, delivery of the final product to the consumers as well as end-of-life management of the product after its useful life' (Srivastava 2007). GrSCM can be seen as being part of a proactive environmental strategy of the lead firm. Such a proactive strategy means that firms are oriented on anticipating and preventing environmental problems by changing policies, instead of merely reacting to isolated events or new environmental regulations (Aragon-Correa, 1998; AragonCorrea and Sharma 2003). Engaging suppliers in GrSCM initiatives is a way to proactively respond to the current changes in society (Berry and Rondinelli 1998).

Awareness of GrSCM is present in all industries. Forerunners are industries related to transportation, for example, the automobile industry (Awaysheh and Klassen 2010). The maritime industry has an increased interest in GrSCM as well (Lai et al. 2011). Similar to the automotive industry, the maritime industry is 'going green'. In particular, public concerns about environmental issues, such as resource depletion and pollution caused by cargo shipping activities have been growing rapidly in the last few years. Furthermore, there are various end-of-life breaking and salvaging effects (Kusumaningdyaha, Eunike, and Yuniarti 2013). Cargo ships release an estimated 1.2-1.6 million tons of airborne particles 
each year, mostly from the burning of heavy fuel oil. These include various carbon particles, and sulphur and nitrogen oxides which have a major impact on the air quality and human health. Cruise liners and cargo ships account for almost $30 \%$ of the world's smog forming nitrogen oxide emissions and nearly $10 \%$ of $\mathrm{SO}_{2}$ emissions from burning fossil fuels. Regulations have been issued by IMO (International Maritime Organization), in which limits for maximum emission of hazardous particles from a ship have been detained (Lai et al. 2011). According to MARPOL (International Convention for the Prevention of Pollution from Ships), these regulations are ground breaking measures to reduce the amount of greenhouse gas emissions from ships. These measures entered into force in 2013, and shipowners as well as shipbuilding companies are required to take actions in order to comply.

The shipbuilding industry has several characteristics that make it interesting and relevant for studying GrSCM practices. A shipbuilding company is typically connected with many contractors operating worldwide, which hinders systematic monitoring and management of environmental pollution that may be caused in the shipbuilding process, as well as noticing environmentally unfriendly work processes and use of polluting materials throughout the supply chain (Chung, Lee, and Lee 2011; Paixao and Marlow 2001). Furthermore, the contractors are each being subject to different local rules and regulations. Each contractor uses different production methods, has different levels of organization and technology, and attaches different priorities to green working methods (Pires and Lamb 2008). Ships have technologically complex product structures, and individual ships are highly customized to buyer demands and wishes. Even vessels from the same series differ from each other, as each vessel is the result of an intense interactive process between various parties (Mello and Strandhagen 2011). Moreover, the project scope is frequently changed by the customer (Venkataraman 2007). This way of working can be identified as engineering to order (Mello and Strandhagen 2011). As a consequence, the design and construction of ships typically involves many partners and subcontractors, and massive information flows (Bolton 2001). Approximately 60-80\% of the value of a vessel is outsourced (Mello and Strandhagen 2011, 2; Held 2010).

Most suppliers in the industry can be characterized as 'jobbers', they follow contractual obligations and do not feel committed or bound to other parties (Levering et al. 2013; Mello and Strandhagen 2011). At the origin of this behaviour lie several factors. First, building a ship represents a large investment, and consequently the roles of partners and subcontractors are defined in contracts that are frequently rigid in nature (Saad, Jones, and James 2002; Levering et al. 2013). Accordingly, sourcing within shipbuilding is highly competitive. Many subcontractors tender on lowest price. Second, shipbuilding includes market niches that require extremely large or specialized equipment, such as docks and cranes (Greve 2003). Numerous parts are needed only in low volume and infrequently, therefore sourcing partners do not build long-term relationship ties to the buyer (Hicks, McGovern, and Earl 2000). Sourcing parties usually are involved for a limited time, which leads to lack of mutual trust and commitment. Furthermore, because of the sheer size of the operation, parties involved in the shipbuilding project typically span many different shipyards and hundreds of suppliers. Hence, they are not inclined to be committed to changing their working methods just to benefit other partners in the project (Ruuska et al. 2013). All these factors could lead to a low commitment to GrSCM initiatives. Thus, green supply chain management in this industry can be considered particularly challenging.

However, over the last decades more and more interdependencies among project partners became required, as technological developments and high knowledge intensity of the project require frequent alignment between partners, and joint problem-solving (Levering et al. 2013). Alignment of ICT systems, but also the adoption of similar 'green' working methods throughout the supply chain is receiving more and more attention by the shipbuilding industry. Hence, green supply chain management in this industry can be considered as upcoming and worthy of study.

Lead companies in supply chains are increasingly investing time and energy in maximizing the environmental capability of their suppliers, for instance by designing supplier development programmes to improve environmental performance. It is obvious that environmental goals can only be reached when suppliers are involved and are dedicated to greening their processes as well, as 
suppliers play a major role in design and production processes of firms. When new environmentally friendly technologies are introduced in the manufacturing process then this is best done in close cooperation with suppliers. Yet, little is known about how suppliers can be involved in green management practices and activities (Carter and Rogers 2008; Caniëls, Gehrsitz, and Semeijn 2013).

Based on the existing literature on GrSCM, sustainable management and green purchasing, influencing factors are formulated for suppliers' participation in the GrSCM initiatives. As a theoretical lens for the choice of our factors we adopt stakeholder theory (Mitchell, Agle, and Wood 1997), which is often applied in studies about GrSCM (e.g. Hofmann et al. 2014). Stakeholder theory states that a firm is influenced by various parties internal and external to the firm which differ in their power, legitimacy, and urgency (Mitchell, Agle, and Wood 1997), and therefore in their basic motives. An organization's performance depends on its capability to react to various stakeholder demands, and to maintain a relationship with various stakeholder groups (Freeman, Wicks, and Parmar 2004; Mitchell, Agle, and Wood 1997). Stakeholders can hold companies accountable for social and environmental outcomes (Parmigiani, Klassen, and Russo 2011), and therefore stakeholders may constitute the key driving force behind GrSCM within organizations. Studies have categorized stakeholder groups in different ways. Often a distinction is made between internal (within the organization) and external (external to the organization) stakeholders (Freeman 1984). In our model (Figure 1), the driving factors of GrSCM reflect internal as well as external stakeholders, including the suppliers themselves, governmental agencies, societal bodies, shareholders, and customers. In the following paragraphs, we will outline each driver of supplier willingness to participate in GrSCM activities in further detail.

We used the model of Lee (2008) as a starting point of this study and enhanced this model by adding competitive and societal drivers as suggested by Holt and Ghobadian (2009), Seuring and Müller (2008), and Khidir et al. (2010). The model of Lee (2008) is particularly relevant for our research objective, as it was developed for small- and medium-sized suppliers. The supplier base of shipbuilding companies typically consists of this type of firms.

\subsection{Grscm readiness}

GrSCM readiness refers to the compliance capabilities of suppliers to take part in the GrSCM initiatives. It is often subject to internal characteristics of supplier companies. Pressure from employees, leadership from an environmentally committed management, and perception of possible

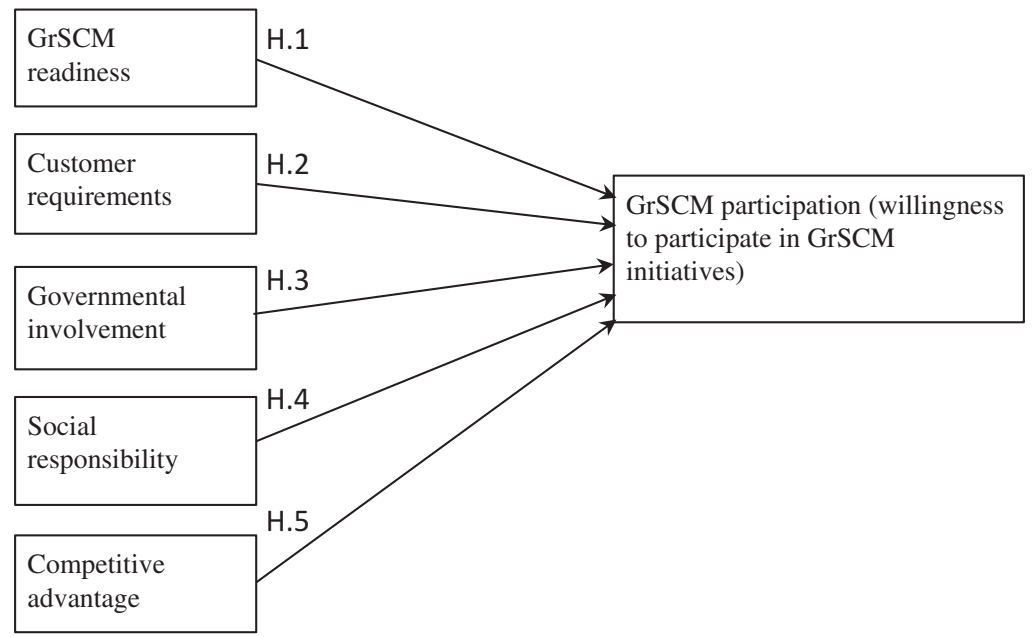

Figure 1. Drivers of GrSCM participation. 
environmental risk might simultaneously contribute to changes in environmental practices in organizations (Holt and Ghobadian 2009). It can be measured by a range of diverse indicators, including manager environmental awareness; cross-functional environmental communication; and human, technical, and financial slack resources (Lee 2008). According to Lippman (1999) and Holt and Ghobadian (2009), commitment from top and middle management is essential for establishing environmental initiatives. Managers and influential individuals, such as CEO's, are mainly responsible for identifying external challenges and deploying internal resources to respond to them. In addition, an environmentally committed organizational culture enhances the ability to facilitate adoption of environmental practices (Green, Morton, and New 2000). Furthermore, quality management and ISO standards are increasingly used by companies seeking to improve their internal operations. King, Lenox, and Terlaak (2005) demonstrated that enterprises that adopt a quality management standard are more likely to adopt an environmental management standard. It is likely that firms that are ready to implement environmental standards, and are aware of the importance of greening their production processes, will be more inclined to participate in GrSCM initiatives of lead companies. We hypothesize:

H1: GrSCM readiness is positively related to the willingness to participate in GrSCM initiatives

\subsection{Customer requirements towards green issues}

In industries such as automotive, customer pressure for green production methods and environmentally friendly products has been object of attention from the 1970s and 1980s onwards. Contrastingly, the shipbuilding market is characterized by industrial customers and the shipbuilding industry lags behind compared to other more consumer-oriented industries in applying green technologies and work approaches. Ships are usually owned by firms that exploit the ship for delivering cargo. Shipowners more and more request shipbuilders to offer environmentally friendly ships, and to employ sustainable production processes, as the shipowners themselves are experiencing pressure from governmental bodies to comply with environmental rules and regulation. In turn, shipbuilding firms require their suppliers to participate in green activities and adopt proactive environmental management practices in order to improve the environmental performance of the entire chain (Lee and Klassen 2008). Sometimes, customers, for example shipbuilders or car manufacturers, require their suppliers to provide them with written certifications of their compliance with all of the environmental regulations (Delmas and Montiel 2009). For example in automotive, Ford Motor Company requires that all its production and non-production suppliers make use of manufacturing facilities for third parties that are certified to ISO 14001 norms (Sroufe and Curkovic 2011). Lead firms put pressure on suppliers to participate in these greening activities to ensure that their purchases sufficiently meet environmental quality standards (Handfield, Krause, and Monczka 2002). Unsatisfactory environmental performance of suppliers could negatively impact the reputation of lead firms in the eyes of end consumers. In contrast, positive environmental performance of suppliers can translate into a competitive advantage for the lead firm (Walton, Handfield, and Melnyk 1998). Hence, the behaviour and attitude of customers and clients with regard to environmental issues may affect a company's willingness to implement environmental practices. We hypothesize:

H2: The existence of customer requirements towards green issues is positively related to the willingness of suppliers to participate in GrSCM initiatives 


\subsection{Governmental involvement in greening the supply chain}

According to Zhu, Sarkis, and Lai (2007), governmental bodies are the most obvious external stakeholders when it comes to environmental issues. Governmental involvement can influence company initiatives by offering a capital rebate for purchasing environmental products, or by indirect encouragement/discouragement via varying tax rates (sales tax, investment tax, tax examinations). For example, the Dutch government provides subsidies for developing vessels that are fuelled by liquefied natural gas (LNG). The advantages of using LNG compared to traditional fuel consist of a reduction of $\mathrm{CO}_{2}$ and $\mathrm{NO}_{\mathrm{x}}$, fine dust, and noise emissions. Subsidies are also granted for greening existing vessels by developing and installing hybrid fuel systems (CBRB 2012). Local or central governments can also provide information and coaching about environmental management, and offer technical assistance to small- and medium-sized firms (Lee 2008). It is likely that suppliers to shipbuilding companies will be willing to participate in various supplier development programmes to improve their environmental performance, when they perceive encouragement and guidance from local or central governments. Therefore, we hypothesize:

H3: The presence of governmental involvement in GrSCM initiatives is positively related to the willingness of suppliers to participate in GrSCM initiatives

\subsection{Social responsibility}

In some cases, a firm's interest in green initiatives can be explained from a sense of responsibility towards society. Environmental problems, such as pollution and global warming, may motivate a firm to behave in a more socially responsible manner and reflect an image of commitment to sustainability and social responsibility (Zhu, Sarkis, and Lai 2008). Scott and Christensen (1995) have shown that the behaviour of an organization may not only be guided by self-interest, but also by awareness of an organization's role in a social situation and a desire to behave appropriately in accordance with the expectations from others and internalized standards of conduct. Over recent years, the society as a whole has become more environmentally aware. The common perception of a company is increasingly influenced by a company's environment reputation, also taking into account its supplier management and purchasing decisions (Walker, Sistob, and McBainc 2008).

Other influential stakeholders, such as green action groups, media, labour unions, and neighbourhood groups, are also motivators for organizations to adopt various environmental practices (Sarkis, Gonzalez-Torre, and Adenso-Diaz 2010; Eesley and Lenox 2006). They can mobilize public opinion in favour or against a company's environmental approach (Henriques and Sadorsky 1999). Financial stakeholders, that is shareholders, can also induce a pressure to adopt green manufacturing practices as shareholders want to maximize the value of the company, which in the public opinion is to some extent related to an environmentally correct behaviour (Reinhardt, Stavins, and Vietor 2008; Golicic and Smith 2013). Pressures of the society on firms to implement green practices might lead to an increased willingness of suppliers to participate in green activities induced by lead firms. Hence:

H4: The existence of social responsibility pressures is positively related to the willingness to participate in GrSCM initiatives

\subsection{Competitive advantage by going green}

Economic opportunities arise when firms engage in green practices. Firms may lower their cost of raw materials and waste disposal by greening their production process (Bansal and Roth 2000; Cordano 
1993). Furthermore, revenues may increase by engaging in ecological activities. For instance, reuse or refurbishing of returned products provides possibilities for deriving information about product use and customer behaviour which may induce further product improvements (Schenkel et al. 2015). Moreover, economic opportunities arise from an improvement of the corporate image (Hart 1995), and from selling waste products. Providing environmental expertise to other firms also generates revenues (Bansal and Roth 2000; Cordano 1993). Having GrSCM capabilities can make a supplier attractive for lead firms that need their suppliers to take an active role in the design and development of new products, services, and processes (Sarkis 2003; Golicic and Smith 2013). Hence, a proactive environmental strategy can help a firm to gain competitive advantage and as a result increase financial performance (Golicic and Smith 2013). 'Proactive' in the field of environmental performance means that an organization perceives environmental improvement as a core competitive organizational dimension for which it wants to continuously build competency.

Companies can lose significant competitive advantages if they refrain from making continuous improvement efforts with respect to environmental management. An example is given by Sarkis (2003), in which a Diesel Engine plant is facing competition because its rival has marketed his new green motors. Even though the Diesel Engine Plant is a pioneer in the field of environmental management, in recent years it has observed more and more competitors with an environmentally competitive dimension. For this Diesel Engine Plant, maintaining its competitive edge and image is a main motivation for this company to implement GrSCM-based practices. All of these arguments lead to the following hypothesis:

H5: Competitive advantage by going green is positively related to the willingness to participate in GrSCM initiatives

\section{Methodology}

\subsection{Sampling, data collection, and measures}

The data collection took place in the Dutch maritime sector which has a leading position in the construction of complex ships. In 2010 the sector had a turnover of 7.2 billion euro's and a total employment of 33,000 FTEs, with an export share of 65\% (as of 2012 listed on the CBS website).

Investigated were suppliers and supply chain partners from Damen Shipyards B.V. and IHC Merwede, which are the two largest shipbuilding companies of the Netherlands. Both shipbuilding companies follow proactive environmental strategies. Currently, these strategies mainly concern product innovation, improvement of production processes, and prevention of a negative impact of the product, that is the ships, on the environment. For instance, the companies actively undertake research with regard to the energy consumption of ships, and investigate alternative fuels and hybrid fuel systems.

Even though the two shipbuilding companies endorsed the study, the data were collected and analysed without company involvement. We gathered data via an online questionnaire. The respondents were not required to report on their experiences specifically with this company, thereby reducing the risk of social desirability bias. Before distributing the survey, the questionnaire was pilot tested by four expert advisors. Target respondents received an invitation to an online questionnaire by email, stating the purpose of the study and assuring confidentially and anonymity. These procedures reduce social desirability bias (Podsakoff et al. 2003).

In total 350 suppliers were approached and 93 responses were collected, resulting in a response rate of $27 \%$. With regard to firm size, $38.7 \%$ of the firms employed less than 49 employees, and $81.7 \%$ of the firms had less than 500 employees. The targeted respondents were executives or functional managers. They had an average working experience of 10-15 years, indicating that the respondents are experienced and knowledgeable in the field. Our study has a high response rate 
compared to previous empirical studies in GrSCM such as Holt and Ghobadian (2009) with a response of $13 \%$, Lee (2008) with $13.4 \%$, and Khidir et al. (2010) with $23.2 \%$.

Data about the independent and dependent variables were both gathered from suppliers, therefore correlations between constructs may be overstated as a result of using a monomethod design (Podsakoff et al. 2003). Spector (2006) and Conway and Lance (2010) demonstrate that the threat of common method bias is generally exaggerated, yet a discussion of this threat to validity is warranted. To abate common method bias, several procedural remedies were undertaken, following Podsakoff et al. (2003). We also examined the potential for common method variance via Harman's one-factor test recommended by Podsakoff and Organ (1986). We executed an unrotated, principal components factor analysis with all manifest variables. We extracted five factors with eigenvalues larger than 1 . The first factor accounted for only $42.1 \%$ of variance. If common method variance were a serious problem in our data, a single factor would have emerged, or one general factor would have accounted for the majority of the covariance in the independent and criterion variables. Overall, we consider the influence of common method variance in our sample to be low.

\subsection{Measures}

Measures were taken from prior validated scales. The measures for the GrSCM readiness, customer requirements towards green issues, governmental involvement in greening the chain and GrSCM participation were adopted from Lee (2008). Scales for competitive advantage by going green and social responsibility were based on Holt and Ghobadian (2009) and Khidir et al. (2010), respectively. All items were measured on 5-point Likert scales (Appendix). We included two control variables in the study by adding items to our questionnaire about: (1) firm size, as this may impact available resources for GrSCM participation; and (2) years of working experience of the respondent, as this may indicate the respondent's knowledgeability in the field.

\subsection{Data analysis}

The analyses were performed using partial least squares (PLS) modelling which is a structural equation modelling (SEM) technique. PLS is particularly adequate for our purposes because of its robustness with respect to multicollinearity (Cassel, Hackel, and Westlund 2000) and violations of the normality distribution assumption, as well as its ability to handle small sample sizes (Haenlein and Kaplan 2004). An overview of conditions under which PLS is more suitable than covariance-based SEM can be found in Wetzels, Odekerken-Schroder, and van Oppen (2009). Besides the fact that PLS can be used for theory confirmation, it can also help to find potential relationships and suggest propositions for future research. The ability to analyse both observed (manifest) and latent variables distinguishes PLS from more traditional techniques such as analysis of variance and multiple regression (Kline 2011). SEM procedures estimate the measurements in two stages. First, the measurement or outer model is evaluated in terms of reliability and validity. Second, the structural or inner model (the structural relationship among the constructs) is assessed (Ringle, Wende, and Will 2005).

\section{Results}

\subsection{Reliability analysis}

Composite reliability, unidimensionality, and construct validity are used for assessing the quality of the measurement model and structural model. Cronbach's alpha of all variables was higher than 0.7 (Appendix), suggesting the items are highly internally consistent. Unidimensionality ensures that each measurement item correlates strongly with its assumed theoretical construct. Factor loadings of our items exceeded 0.5 (Dunn, Seaker, and Waller 1994), thereby fulfilling this criterion. Composite reliability was above the recommended threshold of 0.7 (Nunnally 1978). 
Table 1. Construct correlations.

\begin{tabular}{|c|c|c|c|c|c|c|}
\hline & (1) & $(2)$ & $(3)$ & $(4)$ & (5) & (6) \\
\hline Competitive advantage by going green (1) & .78 & & & & & \\
\hline Customer requirements towards green issues (2) & .50 & .79 & & & & \\
\hline GrSCM participation (3) & .76 & .42 & .86 & & & \\
\hline Governmental involvement in green the supply chain (4) & .42 & .38 & .33 & .80 & & \\
\hline Social responsibility (5) & .69 & .35 & .73 & .38 & .90 & \\
\hline GrSCM readiness $(6)$ & .59 & .48 & .70 & .26 & .58 & .86 \\
\hline AVE & .62 & .62 & .74 & .64 & .81 & .75 \\
\hline Composite reliability & .89 & .87 & .93 & .90 & .96 & .92 \\
\hline
\end{tabular}

All correlations are significant (.05 level). Square root values of average variance extracted on the diagonal.

Furthermore, we assessed construct validity by looking at the construct correlations. The average variance extracted (AVE) should exceed 0.5 and the square root of the AVE of each construct should exceed the correlation of that construct with the remaining constructs. These criteria were met for all constructs (Table 1).

\subsection{Hypothesis testing}

We tested the statistical significance of the parameters in the structural model by bootstrapping with 500 runs (Chin 1998).

In terms of fit of the structural model, the R-squared shows that the independent variables explain nearly $72 \%$ of the variation in willingness to participate in GrSCM activities (Figure 2). Furthermore, three out of five hypotheses were significant. Dashed lines indicate path coefficients that do not significantly differ from zero $(p>0.1)$.

We found that the extent to which suppliers have the capabilities to comply with GrSCM initiatives has a positive influence on the willingness to participate in these initiatives $(\beta=0.12$; $t=2.65$ ), supporting $\mathrm{H} 1$. Suppliers with internal resources like environmental management standards, knowledge about environment issues, financial resources, and human resources show significantly higher willingness to take part in GrSCM initiatives. We do not find support for the hypothesis that customer requirements will have positive influence on the willingness of a supplier to participate in $\operatorname{GrSCM}(\beta=0.06 ; t=0.56)$. Therefore, unlike Lee (2008), we found customer

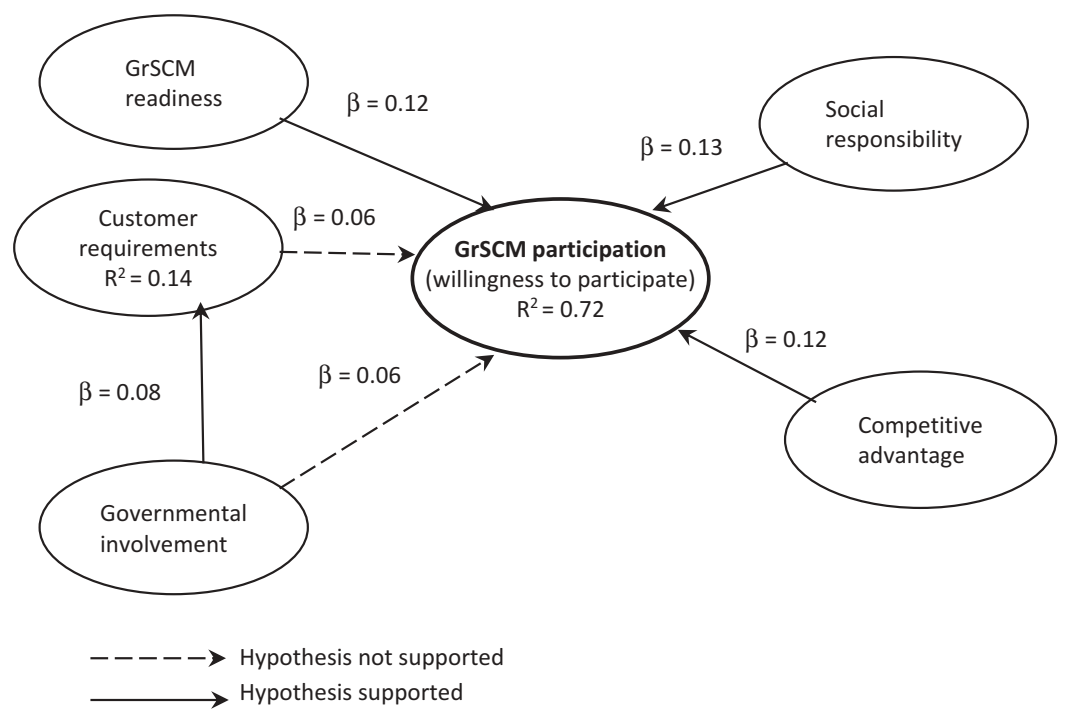

Figure 2. Structural PLS model. 
requirements to be of no influence on the willingness to participate in GrSCM. Despite the fact that customers can require their suppliers to adhere to certain environmental practices, the results for our sample of shipbuilding suppliers indicated that this is not an influential factor. In our sample we also found no support for $\mathrm{H} 3(\beta=0.07 ; t=0.20)$, that companies respond to governmental involvement by a high willingness to participate in GrSCM activities. According to several authors, a firm's interest in green initiatives could be explained by a sense social responsibility towards society and other stakeholders. In our sample this relationship is positive and significant at a $5 \%$ level, supporting $\mathrm{H} 4(\beta=0.12 ; t=2.39)$. Competitive advantage was hypothesized to be positively associated with the supplier's participation in GrSCM initiatives. This was supported by our findings $(\beta=0.12 ; t=3.43)$. Our study included three control variables: firm size, gender, and years of working experience. Only firm size was significant $(\beta=0.06 ; t=1.51)$.

\section{Discussion}

In our sample, competitive advantage, social responsibility, and GrSCM readiness are significant drivers for the supplier's willingness to participate in GrSCM initiatives. No significant effect was found of customer requirements and governmental involvement.

Competitive advantage by going green and GrSCM readiness are significantly related to the willingness to participate in GrSCM. This is in line with non-maritime studies of Lee (2008), Lee and Klassen (2008), Holt and Ghobadian (2009), and the meta study of Golicic and Smith (2013), and thus confirms the findings of these studies, namely that environmental activities of firms are partly related to their specific resources and capabilities (Lee 2008). In our study, the fact that suppliers perceive opportunities for increasing competitive advantage by going green is the most important driver for suppliers to start greening their chain. Apparently, many firms foresee business benefits from these activities and are therefore motivated to adopt these practices. Furthermore, firms may acknowledge that environmental management could result in efficient working processes, which save costs in the long run. Companies simply cannot afford to lag behind their competitors in this respect.

Within our sample we find no support for governmental involvement in greening the supply chain and customer requirements towards green issues as determinants of willingness to participate in GrSCM activities. The explanation for this finding may stem from the fact that we measured the involvement of local or central governments in coordinating the GrSCM initiatives, and providing the funds and infrastructure for these initiatives. Suppliers of shipbuilders are likely to be geographically located outside the incentive and governance span of the-mostly western-governments that undertake these actions. Hence, particularly in the shipbuilding industry, governmental involvement in greening the supply chain may not reach the suppliers. Non-maritime studies find contrasting results (Lee 2008; Holt and Ghobadian 2009; Lee and Klassen 2008; Khidir et al. 2010), and do find a significant impact of government involvement. This is likely to be explained by the large differences in locations and industry types in which each study was performed. The research of Holt and Ghobadian (2009) focused on manufacturing industry in the United Kingdom with mainly respondents from the utilities and public sectors. Lee and Klassen (2008) focused on manufacturing firms in Malaysia, and Khidir et al. (2010) focused on the Korean automobile industry. Levels of support and involvement of the government in greening the supply chain differ greatly between these countries and industries. This also holds for requirements of customers with regard to environmental management incorporated by the supplier. Zhu, Sarkis, and Lai (2008) and Holt and Ghobadian (2009) found that industries have different environmental effects by emissions (toxic, harmful, and ozone depleting) and resources (electricity or fuel) used. Differences in drivers and pressures have caused manufacturers in different industrial sectors to adopt GrSCM practices at different levels. New protocols concerning $\mathrm{CO}_{2}$ emissions from 
international shipping were issued only in 2007, while further regulations entered into force in 2013 (as of 2014 listed on the IMO website). In comparison, the first regulations within the automotive industry were introduced already in the 1980s (An and Sauer 2004). Therefore, the level of customer requirements with regard to green activities of their suppliers is still lagging in the shipbuilding sector, compared to automotive.

In our study, we find that customer requirements towards green issues are not significantly associated with a willingness to implement proactive environmental strategies such as GrSCM. Hence, within the Dutch shipbuilding industry, suppliers are experiencing less pressure and motivation from customer requirements to participate in GrSCM initiatives than is the case for instance in the automotive or electronic industry (Caniëls, Gehrsitz, and Semeijn 2013). The two Dutch shipbuilding companies in our study follow proactive environmental strategies and hence are very interested and active in greening their production processes as well as their products. A possible explanation for our finding, therefore, can be that suppliers in the shipbuilding sector have several alternative outlets for their products. Radar systems can be developed for ships but also for airplanes. In other words, suppliers in the shipbuilding industry may be less dependent on specific buyers than for instance suppliers in the automotive industry which are mostly fully dedicated to car manufacturing. Furthermore, greening initiatives are only recently receiving attention in the shipbuilding industry (IMO, website, 2014). The mindset of shipbuilders and especially of suppliers has to undergo a large shift. Many suppliers are not yet ready to make that leap and try to hold on to traditional manufacturing methods.

Another noteworthy finding concerns the role of social responsibility. Khidir et al. (2010) found that social responsibility is not important, because GrSCM activities require considerable costs and capabilities, which do not seem to outweigh the benefits. Nevertheless, we find the opposite. Apparently the suppliers in our sample attach importance to the image they project on society. Displaying social responsibility may make suppliers attractive for companies that need an active role in the design and development of new products, services, and processes. Specifically, this is the case for the two largest shipbuilding companies of the Netherlands, which are interested in engaging their suppliers in GrSCM activities.

A further remarkable finding is the relationship between customer requirements towards green issues and governmental involvement in greening the supply chain. Focal companies are experiencing encouragement from governmental bodies to comply with certain environmental rules and to reduce environmental impact of their products and production processes. Subsequently, this has implications for the requirements focal companies raise for their suppliers. Preuss (2001) describes this as 'the green multiplier effect', which results from the extension of green management practices from focal companies to immediate suppliers and second-tier suppliers. Therefore, a relationship between governmental involvement in greening the chain and customer requirements towards green issues seems plausible.

Finally, firm size, which is used as a control variable, has a significant impact on the willingness to participate in GrSCM practice. This is in line with the finding of Lee (2008) and indicates that larger firms are more likely to participate in GrSCM practices than smaller firms.

\section{Conclusion}

Although the importance of GrSCM is increasingly being recognized by many enterprises, and studies have shown significant relationships between environmental supply chain practices and firm performance (Golicic and Smith 2013), there still seems to be a lack of motivation for firms to participate in these initiatives. The question arises as to why suppliers in the shipbuilding industry still do not participate in greening initiatives. Current literature highlights several drivers which may affect the choice of participating in GrSCM initiative, but few validate these drivers in practice. Based on existing literature, this study identifies five major factors, and empirically tests them in supply chains of two of the largest shipbuilding companies in the Netherlands, namely 
IHC Merwede and Damen Shipyards. We find a significant relationship to willingness to participate in GrSCM initiatives of (1) GrSCM readiness, (2) social responsibility, and (3) competitive advantage by going green.

Our study is the first effort to investigate GrSCM practices in the shipbuilding industry. The theoretical added value of this paper is threefold. First, this study adds two important drivers to the previous conducted studies, namely competitive advantage by going green and social responsibility, and these are shown to have significant influence on the willingness to participate in GrSCM. Second, we found a significant correlation between customer requirements towards green issues and governmental involvement in greening the supply chain, which is explainable by 'the green multiplier effect'. Third, the current study illustrates the unique character of the shipbuilding industry, as our findings differ from similar non-maritime studies. Differences lie in location and industry character, product lifespan, direct impact on air quality, and levels of pressure and motivation.

Managerial recommendations are as follows. First, this study shows that the presence of customer requirements towards green issues is not a significant driver. Therefore, focal companies should be more active to change this. For instance, they could increase their level of GrSCM practices by increasing the level of investment in the customer-supplier relationships. They should reach out to support suppliers in a proactive and collaborative manner. This is because suppliers were found to be more responsive to their customer environmental performance requirements where increasing levels of relationship-specific investment occurred (Simpson, Power, and Samson 2007). Second, GrSCM readiness appears to be an important driver. Therefore, focal companies should identify suppliers with a high level of financial and human resources to ensure compliance with their requirements. Third, companies could start training their workforce (especially purchasers) for environmental tools such as design for environment, life-cycle analysis, recycling, and other environmentally proactive practices in order to create environmental awareness inside the focal company as well as in the supplier companies, which will consequently benefit their GrSCM practices.

\subsection{Limitations}

Our study has several limitations. A generic limitation of this type of study is that typically the suppliers that are interested in GrSCM activities may have more readily agreed to fill out the questionnaire. The objective of our study was to investigate the drivers of supplier participation in GrSCM initiatives. Hence, insights about drivers from suppliers that indeed are interested in green practices are valuable for our purpose. Nevertheless, future studies may want to investigate obstacles to participation and therefore focus on suppliers that refrain from participating in green initiatives.

Second, we find a high correlation between GrSCM readiness and three other constructs in our sample, yet all correlations are less than the square root of AVE for the GrSCM readiness construct. Respondents apparently are aware of the needs of the other stakeholders, which is in line with stakeholder theory. In contrast, only moderate correlations are observed with customer requirements and green SCM participation. Further research could look into this matter.

Third, our study shows a disconnect between customer requirements and green initiatives at the supplier side. Probably this lack of interest is related to the nature of the shipbuilding industry. In further research the model could be expanded using mediating factors such as customersupplier relationship intensity to study this issue more deeply.

Last, our study is limited to the (global) suppliers of the two largest Dutch shipbuilding companies, while the majority of the world's ships are built in Asia. Since the suppliers in our sample sell their products and services to shipbuilders all over the world, including Asia, we feel that the findings of our study may be generalized for the entire shipbuilding sector. Still, future research may want to broaden our sample and pursue access to supplier databases from the 
world's largest shipbuilders. It would be worthwhile to investigate whether such a worldwide study would arrive at similar outcomes.

\section{Acknowledgements}

The authors want to thank Wilfried Ivens, who helped us with gathering sector-specific information on the shipbuilding industry. This article is a revised and expanded version of a paper entitled Implementing Green Supply Chain Management Practices presented at IPSERA 2013, 24-27 March 2013, Nantes, France, and Academy of Management Annual Meeting, 7-11 August 2015, Vancouver. The authors would like to thank those who attended these presentations for their helpful comments.

\section{Disclosure statement}

No potential conflict of interest was reported by the authors.

\section{ORCID}

Marjolein C. J. Caniëls (i) http://orcid.org/0000-0002-4206-4083

\section{References}

An, F., and A. Sauer. 2004. Comparison of Passenger Vehicle Fuel Economy and Greenhouse Gas Emission Standards around the World. Arlington: Pew Center on Global Climate Change.

Andersen, M., and T. Skjoett-Larsen. 2009. "Corporate Social Responsibility in Global Supply Chains." Supply Chain Management 14 (2): 75-86. doi:10.1108/13598540910941948.

Aragón-Correa, J. A. 1998. "Strategic Proactivity and Firm Approach to the Natural Environment." Academy of Management Journal 41 (5): 556-567. doi:10.2307/256942.

Aragon-Correa, J. A., and S. Sharma. 2003. "A Contingent Resource Based View of Proactive Corporate Environmental Strategy." Academy of Management Review 28 (1): 71-88.

Awaysheh, A., and R. D. Klassen. 2010. "The Impact of Supply Chain Structure on the Use of Supplier Socially Responsible Practices." International Journal of Operations \& Production Management 30 (12): 1246-1268. doi:10.1108/01443571011094253.

Bansal, P., and K. Roth. 2000. "Why Companies Go Green: A Model of Ecological Responsiveness." Academy of Management Journal 43 (4): 717-736. doi:10.2307/1556363.

Berry, M. A., and D. A. Rondinelli. 1998. "Proactive Corporate Environmental Management." Academy of Management Executive 12 (2): 38-50.

Bolton, R. W. 2001. "Enabling Shipbuilding Supply Chain Virtual Enterprises." Journal of Ship Production 17 (2): 76-86.

Caniëls, M. C. J., M. Gehrsitz, and J. Semeijn. 2013. "Participation of Suppliers in Greening Supply Chains.” Journal of Purchasing and Supply Management 19: 134-143. doi:10.1016/j.pursup.2013.02.005.

Carter, C. R., and D. S. Rogers. 2008. "A Framework of Sustainable Supply Chain Management.” International Journal of Physical Distribution and Logistics Management 38 (5): 360-387. doi:10.1108/09600030810882816.

Cassel, C. M., P. Hackel, and A. H. Westlund. 2000. "On Measurement of Intangible Assets." Total Quality Management 11 (7): 897-907. doi:10.1080/09544120050135443.

CBRB. 2012. Jaarverslag 2014. Rotterdam: CBRB.

Chin, W. 1998. "The Partial Least Squares Approach to Structural Equation Modelling." In Modern Methods for Business Research, edited by G. Marcoulides, 295-358. Mahwah: Lawrence Erlbaum.

Chung, J.-W., M.-E. Lee, and H.-D. Lee. 2011. "Characteristics of Environmental Pollution Related with Public Complaints in an Industrial Shipbuilding Complex, Korea." Environmental Monitoring and Assessment 177: 7384. doi:10.1007/s10661-010-1619-9.

Conway, J. M., and C. E. Lance. 2010. "What Reviewers Should Expect from Authors regarding Common Method Bias in Organizational Research." Journal of Business Psychology 25: 325-334. doi:10.1007/s10869-010-9181-6.

Cordano, M. 1993. "Making the Natural Connection: Justifying Investment in Environmental Innovation." In Proceedings of the International Association for Business and Society, 530-537. New York: PhilPapers.

Cronin, J., J. Smith, M. R. Gleim, and J. Martinez. 2011. "Green Marketing Strategies: An Examination of Stakeholders and the Opportunities They Present." Journal of the Academy of Marketing Science 39: 158-174. doi:10.1007/s11747-010-0227-0. 
Delmas, M. A., and I. Montiel. 2009. “Greening the Supply Chain.” Journal of Economics \& Management Strategy 18 (1): 171-201. doi:10.1111/j.1530-9134.2009.00211.x.

Dunn, S. C., R. F. Seaker, and M. A. Waller. 1994. "Latent Variables in Business Logistics Research." Journal of Business Logistics 15 (2): 145-172.

Eesley, C., and M. J. Lenox. 2006. "Firm Responses to Secondary Stakeholder Action." Strategic Management Journal 27: 765-781. doi:10.1002/(ISSN)1097-0266.

Freeman, R. E.. 1984. Strategic Management: A Stakeholder Approach. Boston, MA: Pitman.

Freeman, R. E., A. C. Wicks, and B. Parmar. 2004. "Stakeholder Theory and "The Corporate Objective Revisited"." Organization Science 15 (3): 364-369. doi:10.1287/orsc.1040.0066.

Golicic, S. L., and C. D. Smith. 2013. "A Meta-Analysis of Environmentally Sustainable Supply Chain Management Practices and Firm Performance." Journal of Supply Chain Management 49 (2): 78-95. doi:10.1111/jscm.2013.49. issue-2.

Green, K., B. Morton, and S. New. 2000. “Greening Organization.” Organization \& Environment 13 (2): $206-225$. doi:10.1177/1086026600132003.

Greve, H. R. 2003. "Investment and the Behavioral Theory of the Firm." Industrial and Corporate Change 12 (5): 1051-1076. doi:10.1093/icc/12.5.1051.

Haenlein, M., and A. M. Kaplan. 2004. “A Beginner's Guide to Partial Least Square Analysis.” Understanding Statistics 3 (4): 283-297. doi:10.1207/s15328031us0304_4.

Handfield, R., D. T. S. Krause, and R. Monczka. 2002. “Avoid the Pitfalls in Supplier Development." Sloan Management Review 41: 37-52.

Hart, S. L. 1995. “A Natural-Resource-Based View of the Firm.” Academy of Management Journal 37: 986-1014.

Held, T. 2010. "Supplier Integration as an Improvement Driver." In Supply Chain Network Management, edited by C. Engelhardt-Nowitzki, O. Nowitzki, and H. Zsifkovits. Wiesbaden: Gabler Verlag.

Henriques, I., and P. Sadorsky. 1999. "The Relationship between Environmental Commitment and Managerial Perceptions of Stakeholder Importance.” Academy of Management Journal 42 (1): 87-99. doi:10.2307/256876.

Hicks, C., T. McGovern, and C. F. Earl. 2000. "Supply Chain Management: A Strategic Issue in Engineer to Order Manufacturing." International Journal of Production Economics 65: 179-190. doi:10.1016/S0925-5273(99)000262.

Hofmann, H., C. Busse, C. Bode, and M. Henke. 2014. "Sustainability-Related Supply Chain Risks." Business Strategy and the Environment 23 (3): 160-172. doi:10.1002/bse.1778.

Holt, D., and A. Ghobadian. 2009. "An Empirical Study of Green Supply Chain Management Practices Amongst UK Manufacturers.” Journal of Manufacturing Technology Management 20 (7): 933-956. doi:10.1108/ 17410380910984212.

Kang, Y., M. Ryu, and S. Kim. 2010. "Exploring Sustainability Management for Telecommunications Services." Journal of World Business 45: 415-421. doi:10.1016/j.jwb.2009.08.003.

Khidir, T., E. Tayeb, S. Zailani, and K. Jayaraman. 2010. “The Examination on the Drivers for Green Purchasing Adoption among EMS 14001 Certified Companies in Malaysia.” Journal of Manufacturing Technology Management 21 (2): 206-225. doi:10.1108/17410381011014378.

King, A., M. J. Lenox, and A. Terlaak. 2005. "The Strategic Use of Decentralized Institutions." Academy of Management Journal 48 (6): 1091-1106. doi:10.5465/AMJ.2005.19573111.

Kline, R. B. 2011. Principles and Practice of Structural Equation Modeling. New York: Guilford Press.

Koller, M., A. Floh, and A. Zauner. 2011. "Further Insights into Perceived Value and Consumer Loyalty." Psychology \& Marketing 28 (12): 1154-1176. doi:10.1002/mar.v28.12.

Kusumaningdyaha, W., A. Eunike, and R. Yuniarti. 2013. "Modeling Tradeoff in Ship Breaking Industry Considering Sustainability Aspects." Procedia Environmental Sciences 17: 785-794. doi:10.1016/j. proenv.2013.02.096.

Lai, K. H., Y. H. Luna, C. Wong, and T. C. E. Cheng. 2011. "Green Shipping Practices in the Shipping Industry." Resources, Conservation and Recycling 55: 631-638. doi:10.1016/j.resconrec.2010.12.004.

Lam, J. S. L., and E. Van De Voorde. 2011. "Scenario Analysis for Supply Chain Integration in Container Shipping." Maritime Policy \& Management 38 (7): 705-725. doi:10.1080/03088839.2011.625988.

Lee, S. 2008. "Drivers for the Participation of Small and Medium-Sized Suppliers in Green Supply Chain Initiatives." Supply Chain Management 13 (3): 185-198. doi:10.1108/13598540810871235.

Lee, S., and R. D. Klassen. 2008. "Drivers and Enablers that Foster Environmental Management Capabilities in Small and Medium-Sized Suppliers in Supply Chains.” Production and Operations Management 17 (6): $573-586$. doi:10.3401/poms.1080.0063.

Levering, R., R. Ligthart, N. Noorderhaven, and L. Oerlemans. 2013. "Continuity and Change in Interorganizational Project Practices.” International Journal of Project Management 31: 735-747. doi:10.1016/j.ijproman.2012.12.010.

Lippman, S. 1999. "Supply Chain Environmental Management." Environmental Management 6 (2): 175-182.

Lu, B. Z., and A. S. T. Tang. 2000. "China Shipbuilding Management Challenges in the 1980s.” Maritime Policy \& Management 27 (1): 71-78. doi:10.1080/030888300286707. 
Mello, M. H., and J. O. Strandhagen. 2011. "Supply Chain Management in the Shipbuilding Industry." Journal of Engineering for the Maritime Environment 225 (3): 261-270.

Mitchell, R., B. Agle, and D. Wood. 1997. “Toward a Theory of Stakeholder Identification and Salience.” Academy of Management Review 22 (4): 853-886.

Nunnally, J. 1978. Psychometric Theory. New York: McGraw-Hill.

Paixao, A. C., and P. B. Marlow. 2001. "A Review of the European Union Shipping Policy." Maritime Policy \& Management 28 (2): 187-198. doi:10.1080/03088830118389.

Parmigiani, A., R. D. Klassen, and M. V. Russo. 2011. "Efficiency Meets Accountability.” Journal of Operations Management 29: 212-223. doi:10.1016/j.jom.2011.01.001.

Pires, F. C. M., and T. Lamb. 2008. "Establishing Performance Targets for Shipbuilding Policies.” Maritime Policy \& Management 35 (5): 491-502. doi:10.1080/03088830802352129.

Podsakoff, P. M., S. B. MacKenzie, J.-Y. Lee, and N. P. Podsakoff. 2003. "Common Method Biases in Behavioral Research.” Journal of Applied Psychology 88 (5): 879-903. doi:10.1037/0021-9010.88.5.879.

Podsakoff, P. M., and D. W. Organ. 1986. "Self-Reports in Organizational Research.” Journal of Management 12 (4): 531-544. doi:10.1177/014920638601200408.

Prahinski, C., and C. Kocabasoglu. 2006. "Empirical Research Opportunities in Reverse Supply Chains.” Omega 34 (6): 519-532. doi:10.1016/j.omega.2005.01.003.

Preuss, L. 2001. "In Dirty Chains? Purchasing and Greener Manufacturing." Journal of Business Ethics 34: 345-359. doi:10.1023/A:1012549318786.

Reinhardt, F. L., R. N. Stavins, and R. H. K. Vietor. 2008. "Corporate Social Responsibility through an Economic Lens." Review of Environmental Economics and Policy 2 (2): 219-239. doi:10.1093/reep/ren008.

Ringle, C., S. Wende, and A. Will. 2005. SmartPLS, 2.0 ed. www.smartpls.de

Ruuska, I., T. Ahola, M. Martinsuo, and T. Westerholm. 2013. "Supplier Capabilities in Large Shipbuilding Projects.” International Journal of Project Management 31: 542-553. doi:10.1016/j.ijproman.2012.09.017.

Saad, M., M. Jones, and P. James. 2002. "A Review of the Progress Towards the Adoption of Supply Chain Management Relationships in Construction.” European Journal of Purchasing \& Supply Management 8: $173-183$. doi:10.1016/S0969-7012(02)00007-2.

Sarkis, J. 2003. “A Strategic Decision Framework for Green Supply Chain Management.” Journal of Cleaner Production 11 (4): 397-409. doi:10.1016/S0959-6526(02)00062-8.

Sarkis, J., P. Gonzalez-Torre, and B. Adenso-Diaz. 2010. "Stakeholder Pressure and the Adoption of Environmental Practices." Journal of Operations Management 28: 163-176. doi:10.1016/j.jom.2009.10.001.

Schenkel, M., H. R. Krikke, M. C. J. Caniëls, and E. Van Der Laan. 2015. "Creating Integral Value for Stakeholders in Closed Loop Supply Chains.” Journal of Purchasing and Supply Management 21 (3): 155-166. doi:10.1016/j. pursup.2015.04.003.

Scott, W. R., and S. Christensen. 1995. The Institutional Construction of Organizations. Thousand Oaks: Sage.

Seuring, S., and M. Müller. 2008. "From a Literature Review to a Conceptual Framework for Sustainable Supply Chain Management." Journal of Cleaner Production 16: 1699-1710. doi:10.1016/j.jclepro.2008.04.020.

Simpson, D., D. Power, and D. Samson. 2007. "Greening the Automotive Supply Chain." International Journal of Operations \& Production Management 27 (1): 28-48. doi:10.1108/01443570710714529.

Spector, P. E. 2006. "Method Variance in Organizational Research.” Organizational Research Methods 9: $221-232$. doi:10.1177/1094428105284955.

Srivastava, S. K. 2007. “Green Supply Chain Management.” International Journal of Management Reviews 9 (1): $53-$ 80. doi:10.1111/j.1468-2370.2007.00202.x.

Sroufe, R., and S. Curkovic. 2011. “An Examination of ISO 9000.” Journal of Operations Management 26 (4): $503-$ 520. doi:10.1016/j.jom.2007.06.006.

Venkataraman, R. 2007. "Project Supply Chain Management.” In The Wiley Guide to Managing Projects, edited by P. W. G. Morris and J. K. Pinto. Hoboken: Wiley.

Walker, H., L. Sistob, and D. McBainc. 2008. "Drivers and Barriers to Environmental Supply Chain Management Practices." Journal of Purchasing \& Supply Management 14: 69-85. doi:10.1016/j.pursup.2008.01.007.

Walton, S. V., R. B. Handfield, and S. A. Melnyk. 1998. “The Green Supply Chain.” International Journal of Purchasing and Materials Management 34 (1): 2-11. doi:10.1111/j.1745-493X.1998.tb00042.x.

Wetzels, M., G. Odekerken-Schroder, and C. van Oppen. 2009. "Using PLS Path Modeling for Assessing Hierarchical Construct Models.” MIS Quarterly 33 (1): 177-195.

Xu, L., K. Mathiyazhagan, K. Govindan, A. Noorul Haqc, N. V. Ramachandran, and A. Ashokkumar. 2013. "Multiple Comparative Studies of Green Supply Chain Management." Resources, Conservation and Recycling 78: 26-35. doi:10.1016/j.resconrec.2013.05.005.

Zhu, Q., J. Sarkis, and K.-H. Lai. 2007. “Green Supply Chain Management: Pressures, Practices and Performance within the Chinese Automobile Industry." Journal of Cleaner Production 15: 1041-1052. doi:10.1016/j. jclepro.2006.05.021.

Zhu, Q., J. Sarkis, and K.-H. Lai. 2008. “Green Supply Chain Management Implications for “Closing the Loop”.” Transportation Research Part E 44: 1-18. doi:10.1016/j.tre.2006.06.003. 


\section{Appendix. Descriptive statistics on item level}

\begin{tabular}{|c|c|c|c|}
\hline Construct & Items & $\begin{array}{c}\text { Alpha } \\
\text { (\#items) }\end{array}$ & $\begin{array}{l}\text { Mean } \\
\text { (SD) }\end{array}$ \\
\hline $\begin{array}{l}\text { GrSCM readiness } \\
\quad \text { (Lee 2008) }\end{array}$ & $\begin{array}{l}\text { Our managers are aware of the importance of environmental } \\
\text { issues. } \\
\text { Environmental issues are well communicated between the } \\
\text { environmental function and other departments. } \\
\text { An environmental management system is established. } \\
\text { Our firm has financial reserves to invest in advanced technologies, } \\
\text { including environmental solutions. } \\
\text { Our firm has information and know-how relating to emerging } \\
\text { environmental issues in our industry. } \\
\text { Our firm has human resources to deal with emerging } \\
\text { environmental issues in our industry. }\end{array}$ & $.95(6)$ & 3.99 (1.02) \\
\hline $\begin{array}{l}\text { Customer requirements towards } \\
\text { green issues } \\
\text { (Lee 2008) }\end{array}$ & $\begin{array}{l}\text { Our major buyers incorporate environmental considerations in } \\
\text { selecting their supplies and suppliers. } \\
\text { Our major buyers request us to have an environmental } \\
\text { management system (e.g. ISO 14001). } \\
\text { Our major buyers have interest in greening the supply chain. } \\
\text { Our major buyers provide us with environmental training, } \\
\text { education, or technical assistance. }\end{array}$ & $.80(4)$ & $3.00(0.85)$ \\
\hline $\begin{array}{l}\text { Governmental involvement in } \\
\text { greening the chain } \\
\text { (Lee 2008) }\end{array}$ & $\begin{array}{l}\text { Local or central governments coordinate the GrSCM initiatives. } \\
\text { Local or central governments increase funds for the GrSCM } \\
\text { initiatives. } \\
\text { Local or central governments provide information and technical } \\
\text { assistance to small- and medium-sized firms. } \\
\text { Local or central governments popularize knowledge of } \\
\text { environmental management. } \\
\text { Local or central governments build infrastructure for facilitating } \\
\text { GrSCM initiatives. }\end{array}$ & $.91(5)$ & $2.68(0.94)$ \\
\hline $\begin{array}{l}\text { Social responsibility } \\
\text { (based on Holt and Ghobadian } \\
2009 \text { and Khidir et al. 2010) }\end{array}$ & $\begin{array}{l}\text { Our firm is maintaining or presenting an environmentally or } \\
\text { socially responsible image. } \\
\text { Our organization presents itself as an environmentally responsible } \\
\text { company. } \\
\text { Our firm tries to meet the societal expectation. } \\
\text { Our firm is subjected to pressure from the insurance industry. } \\
\text { Our firm is subjected to pressure from shareholders or investors } \\
\text { (when applicable). }\end{array}$ & $.86(5)$ & $3.49(0.96)$ \\
\hline $\begin{array}{l}\text { Competitive advantage by going } \\
\text { green } \\
\text { (based on Holt and Ghobadian } \\
2009 \text { and Khidir et al. 2010) }\end{array}$ & $\begin{array}{l}\text { Our firm tries to perform better than our competitors } \\
\text { or equivalent institutions. } \\
\text { GrSCM provides new market opportunities. } \\
\text { Our firm tries to match the activities of competitors. } \\
\text { Green initiatives provides operational cost savings. } \\
\text { Green supply chain initiatives are generally considered in my } \\
\text { firm's industry as having considerable marketing benefits. }\end{array}$ & $.84(5)$ & $3.62(0.93)$ \\
\hline $\begin{array}{l}\text { GrSCM participation } \\
\quad \text { (Lee 2008) }\end{array}$ & $\begin{array}{l}\text { Our firm is aware of the GrSCM initiatives. } \\
\text { Our firm is willing to participate in the GrSCM initiatives. } \\
\text { Our firm has managers who have interest in the GrSCM initiatives. } \\
\text { Our firm expects environmental and economic benefits from the } \\
\text { GrSCM initiatives. }\end{array}$ & $.89(4)$ & $3.79(0.85)$ \\
\hline
\end{tabular}

